\title{
Method of designing technology for future teacher intellectual work culture formation
}

\section{Método de projetar tecnologia para o futuro professor de formação de cultura de trabalho intelectual}

\section{Método de diseño de tecnología para la formación de la cultura del trabajo intelectual del futuro docente}

\author{
Alexandr Albertovich Mukhametshin ${ }^{1}$ iD, Ramis Rafagatovich Nasibullov ${ }^{1}$ iD, \\ Valentina Khamitovna Adilova² iD
}

\author{
${ }^{1}$ Kazan Federal University, Kazan, Russia. \\ ${ }^{2}$ Pavlodar State University named after S. Toraigyrova Pavlodar State University, Pavlodar, Kazakhstan. \\ Corresponding author: \\ Alexandr Albertovich Mukhametshin \\ Email: maa@bina.pro
}

How to cite: Mukhametshin, A. A., Nasibullov, R. R., \& Adilova, V. K. (2021). Method of designing technology for future teacher intellectual work culture formation. Revista Tempos e Espaços em Educação, 14(33), e15250.

http://dx.doi.org/10.20952/revtee.v14i33.15250

\begin{abstract}
Relevance of the problem under study is due to the need for monitoring diagnostics of the intellectual work culture formation of future teacher and the lack of development of specific ways, approaches and conditions of technology as a way of its qualitative design. The purpose of the article is to develop a method for designing the technology for forming the future teacher's intellectual work culture in line with the anthropological paradigm and testing it. Research methods: the leading method of researching this problem is modeling a method of designing technology, which allows analyzing the methodological, theoretical, technological and practical ways, approaches and conditions for future teacher intellectual work culture formation. Results of the research: the article presents a method of designing technology for future teacher intellectual work culture formation, consisting of differentiation of ways, psychological and pedagogical conditions, and effective approaches established through monitoring diagnostics and determining the goal of its concept in line with the anthropological paradigm. Practical significance: The method of designing technology for future teacher intellectual work culture formation is aimed at transforming specific types of activity of the students on the basis of quality determination, the efficiency and effectiveness of the ways policies and conditions by means of monitoring diagnostics.

Keywords: Method of designing technology. Monitoring diagnostics. Ways. Approaches. Conditions.
\end{abstract}




\section{RESUMO}

A relevância do problema em estudo se deve à necessidade de diagnósticos de acompanhamento da formação da cultura intelectual do trabalho do futuro professor e à falta de desenvolvimento de formas, abordagens e condições específicas da tecnologia como forma de seu desenho qualitativo. O objetivo do artigo é desenvolver um método para projetar a tecnologia para formar a cultura intelectual do trabalho do futuro professor em consonância com o paradigma antropológico e testálo. Métodos de investigação: o principal método de investigação deste problema é a modelação de um método de concepção de tecnologia, que permite analisar os caminhos, abordagens e condições metodológicas, teóricas, tecnológicas e práticas para a formação da cultura intelectual do futuro professor. Resultados da pesquisa: o artigo apresenta um método de desenho de tecnologia para a formação da cultura intelectual do futuro professor, que consiste na diferenciação de caminhos, condições psicológicas e pedagógicas e abordagens efetivas estabelecidas por meio de diagnósticos de monitoramento e determinação do objetivo de seu conceito em consonância com os paradigmas antropológicos. Significado prático: O método de desenho de tecnologia para a formação da cultura intelectual do futuro docente visa transformar tipos específicos de atividade dos alunos em função da determinação da qualidade, da eficiência e eficácia das políticas e condições das formas por meio de diagnósticos de monitoramento.

Palavras-chave: Método de projetar tecnologia. Diagnóstico de monitoramento. Maneiras. Abordagens. Condições.

\section{RESUMEN}

La relevancia del problema en estudio se debe a la necesidad de monitorear diagnósticos de la formación de la cultura del trabajo intelectual del futuro docente y la falta de desarrollo de formas, enfoques y condiciones específicas de la tecnología como vía de su diseño cualitativo. El propósito del artículo es desarrollar un método para diseñar la tecnología para formar la cultura del trabajo intelectual del futuro docente en línea con el paradigma antropológico y probarlo. Métodos de investigación: el método principal para investigar este problema es la modelación de un método de diseño de tecnología, que permita analizar las formas, enfoques y condiciones metodológicas, teóricas, tecnológicas y prácticas para la formación de la cultura del trabajo intelectual del futuro docente. Resultados de la investigación: el artículo presenta un método de diseño de tecnología para la formación de la cultura del trabajo intelectual del futuro docente, consistente en la diferenciación de formas, condiciones psicológicas y pedagógicas, y enfoques efectivos establecidos a través de diagnósticos de seguimiento y determinación del objetivo de su concepto en línea con la paradigma antropológico. Importancia práctica: El método de diseño de tecnología para la formación de la cultura del trabajo intelectual del futuro docente tiene como objetivo transformar tipos específicos de actividad de los estudiantes sobre la base de la determinación de la calidad, la eficiencia y eficacia de las formas políticas y condiciones mediante diagnósticos de seguimiento.

Palabras clave: Método de diseño de tecnología. Seguimiento de los diagnósticos. Formas. Enfoques. Condiciones.

\section{INTRODUCTION}

Improving the state policy in the field of education and ensuring quality education in the Republic of Kazakhstan has been approved by the state program for the development of education and science, which defines the main strategic directions and tactical tasks for the development of the education system for the period up to 2025 .

The program provides for the implementation of innovative changes in the development and implementation of new training technologies aimed at improving the quality of education and operational changes in the sphere of professional activity of the future specialist. Current trends in improving training technology and the challenges facing different levels of its use make it necessary 
to rethink ways, approaches, and conditions, develop new ways to design them and further develop them [State program for the development of education and science of the Republic of Kazakhstan for 2016].

The problem of how to design the technology for future teacher intellectual work culture formation in order to develop a complete human personality is a priority anthropological task that is of value for modern education. The ability of a person to independently develop ways, develop approaches and determine the necessary conditions serves as an essential basis for the formation of an intellectual work culture at different stages of education, the formation of a person's subjectivity as a need and the ability to self-determined, self-organized, self-regulated and selfcontrolled behavior tactics (Kuzmina, 1995; Adilova, 2017).

\section{METHODOLOGY}

\section{Research methods}

The following methods were used in the research process: theoretical (analysis; synthesis; classification; comparison; method of induction and deduction; modeling); diagnostic (questionnaires; testing; method of tasks and tasks); empirical (study of the experience of educational organizations, legal and educational documentation; pedagogical observation); experimental (ascertaining, forming, control experiments); methods of mathematical statistics and graphical representation of results.

\section{Experimental base of the study}

The experimental base of the research were S. Toraighyrov Pavlodar State University (Pavlodar) and Kazan Federal University (Kazan).

\section{Investigation stages}

The study of the problem was carried out in three stages. At the first stage, a methodological and theoretical analysis of existing approaches and ways in the philosophical, psychological and pedagogical scientific literature, dissertations on the problem, as well as the theory and methodology of pedagogical research was carried out; the problem, goal, and methods of research were identified, and an experimental research plan was drawn up. At the second stage, foreign experience of monitoring diagnostics use by future teachers ways and approaches was studied, psychological and pedagogical conditions were identified, model of intellectual culture work technology was described associated with the development of designing technology; the meaning of the experimental work was clarified, comprehensive training programmes of compulsory subjects and optional courses were developed and amended, psychological and pedagogical experiment were conducted. The third stage included analysis of the integrity of the concept of creating a culture of intellectual labor, its methodological theory, technologies and practices based on the anthropological paradigm that opens the opportunity to reveal a method of designing technology, mathematical processing, systematization and interpretation of the results, conclusions, completed the study.

\section{RESULTS AND DISCUSSION}

\section{Structure and content of the method}

The anthropological approach ensures the complexity of the design process, taking into account the external and internal connections of paths and approaches, the implementation of which requires a single, end-to-end and adequate to the design stages of the system description of the technology content. The basis of the development of the technology design method is the study 
of ways, approaches and conditions that determine the content of the existing system, specifying the necessary changes and innovations in the aspects of describing parts of the system development. Disclosure of potential capabilities of an intellectual work specialist is based on:

- reflection and understanding;

- action techniques and communication mechanisms;

- interpretation and thinking;

- self-determination in culture and its introduction into society;

- social and cultural personification;

- goal-setting;

- organization of the knowledge system.

Ways of intellectual work culture formation based on the anthropological approach are differentiated as follows (Figure1).

Figure 1. Ways of intellectual work culture formation.

- original source of information

- the solution of cognitive tasks:

- observation

-research

\section{original source of} knowledge about yourself

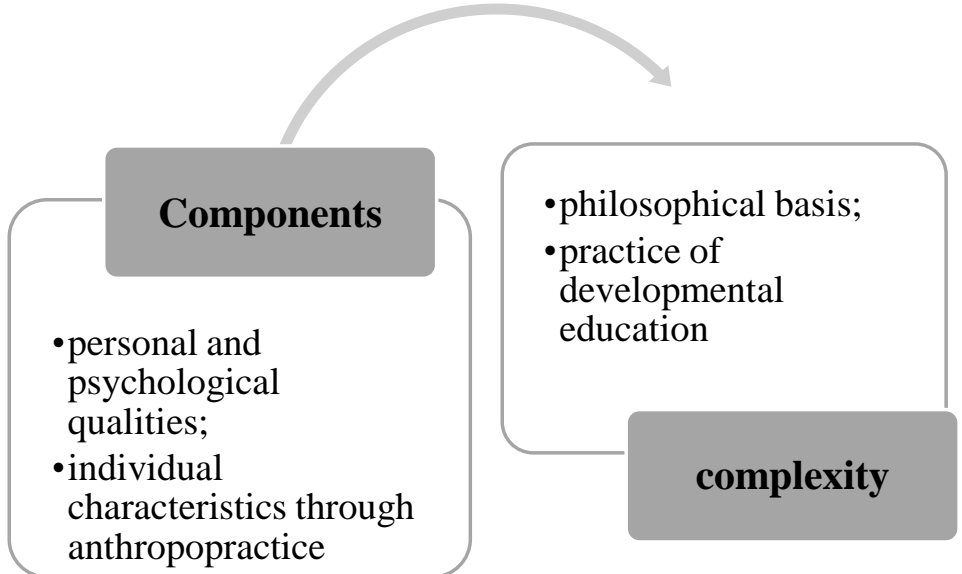

Important principles aimed at implementing ways to form intellectual work culture are:

- managing your own activities;

- rationalism as the basis of the worldview:

a) cognoscibility;

b) technical mastery of laws and mechanisms;

- meaning-forming activity as achievement of goals and objectives;

- the principle of well-being-taking appropriate measures to restore order;

- the intrinsic value is an absolute value and protection.

These principles can be implemented under certain psychological and pedagogical conditions. For their consideration, it is necessary to identify and determine the ways of forming a culture of intellectual labor through active activity and work system, which will lead to its acquirement in the process of fully organized activities (Figure 2). 
Figure 2. Conditions as a basis for component formation of intellectual work culture.

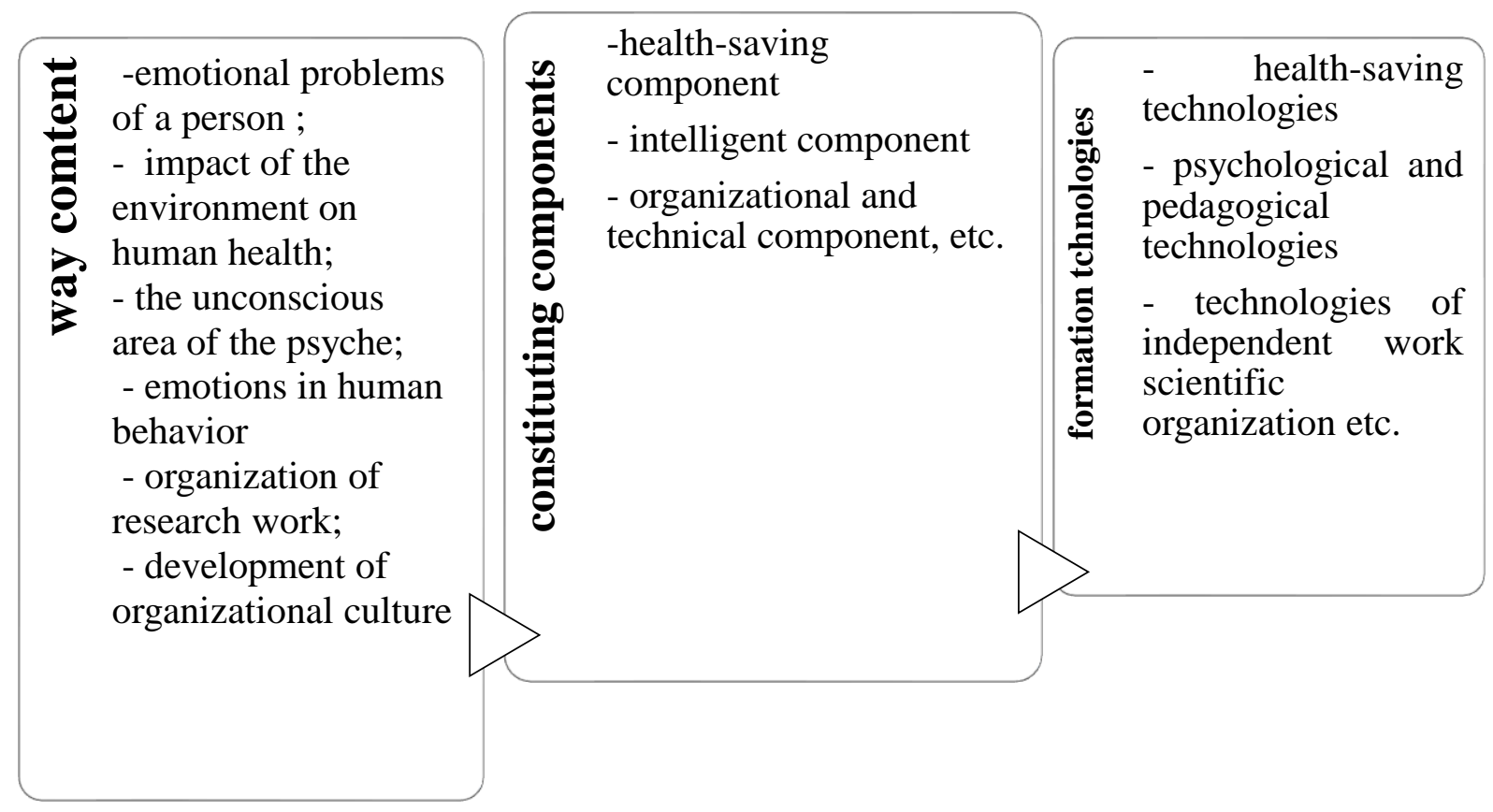

The psychological and pedagogical conditions that form the basis of the component formation of intellectual work culture in the structure of the anthropological paradigm reveal its mechanisms and constitute a symbiosis of all paths or a complex, since they are aimed at personal improvement through active activity.

Mechanisms of components of intellectual labor culture formation in the structure of the anthropological paradigm allow:

- build a relationship as a system;

- predicted result;

- highlight the content aspect of the component;

- define understandings of meanings of different orders;

- identify the content side of reflexive strategy and tactics.

The anthropological paradigm of the culture of intellectual work formation allows us to justify the designing technologies method at various levels of the research. The philosophical level of research on of intellectual work culture formation is determined by materialistic dialectics. Dialectics as a universal method of intellectual work culture cognition and the theory of personal development reveal the main positions of cause-and-effect relationships and phenomena of reality, consider the construction of mechanisms for the intellectual work culture formation in the relationships and interdependencies (Slobodchikov \& Issaev, 1995).

Conceptual provisions for the intellectual work culture formation at the specific scientific level are based on acmeological, cultural, competence, contextual, technological and analytical, information and qualimetric approaches.

The acmeological approach as a progress in personal and professional development allows us to study productive development and self-realization through their laws, mechanisms, conditions and factors (Mezinov \& Zakharova, 2019).

This ensures clarity, order, sufficiency, completeness, integrity and objectivity of information about the level of preparedness and the degree of professional and personal development. It uses the theory of pedagogical measurements, mass character, independence of expert evaluation procedures, testing, methods of mathematical statistics and pedagogical interpretation of the analysis (Amhag et al., 2019). 
The dynamics and direction of the intellectual work culture among students in educational process of the $\mathrm{HEl}$ is determined within the framework of this technology. The structure of the technology for intellectual work culture formation includes purposeful, structural and content, process, effective and reflexive-corrective blocks (Yarullin et al., 2018).

The target block of the technology is aimed at the use of students:

- motivational and value methods in the process of intellectual activity in society;

- critical thinking techniques;

- informational and informative materials and objective self-assessment;

- manifestation of the personal-important qualities;

- general and cultural and professional competencies.

The implementation of the structural and content block of technology is aimed at creating an image of the future teacher, developing the content of the technology, portfolio, program, competencies, and labor functions that contribute to the formation of a culture of intellectual work.

The implementation of the content and process block of the technology is aimed at organizing and planning instrumental operations, designing the "image of the future teacher".

The content and process block of the technology provides for the use of methods, forms, and tools. The goal of the performance block is to analyze the results of technology implementation in the educational process.

At the reflexive-corrective stage, students need to master the skills of analyzing and correcting their own work, activities, and implement its results in practice. One of the tasks of acmeological support of CIW formation is shown in figure 3.

Ways and approaches are based on the conceptual positions of dialectics as a universal method of intellectual work culture cognition, the theory of personal development, the theory of system-activity approach at the general scientific level and specific scientific approaches (Figure 4).

\section{Stages of method implementation}

The implementation of the technology design method involved the following stages of experimental work:

- determination of the initial level of formation of monitoring skills of future teachers using methods of testing, questionnaire survey, pedagogical observation and self-observation, statistical processing of research results (Potashnik, 2006).

In this regard, the main provisions of ways, approaches and conditions for the formation of a culture of intellectual labor that determine the content of monitoring skills are highlighted:

- understanding the essence of the phenomenon being studied;

- assimilation of knowledge about the specific features of intellectual work culture;

- applicability of functions, actions, and competencies in practice;

- analysis of knowledge, skills, methods of action for the intellectual work culture, systematization, generalization and dissemination. These stages must be carried out, taking into account the characteristics and goals of training, the formation of competencies, with the need for self-esteem and self-actualization. The basis of development and self-realization is intellectual maturity as an individual quality and the main indicator of personal competence.

On the basis of knowledge of cultural theory, the personal information socio-cultural space is expanded and the essence of intellectual work culture is revealed, laws, functions, factors, features of thinking, speech, and activity in relation to the general culture are revealed.

The technological approach is associated with the use of basic educational procedures for the formation of intellectual work culture, aimed at personal and professional growth of students. These are developing technologies, problem-based learning, health-saving and computer technologies (Barinova \& Karunas, 2015). 
Figure 3. Some aspects of content and process block of the technology.

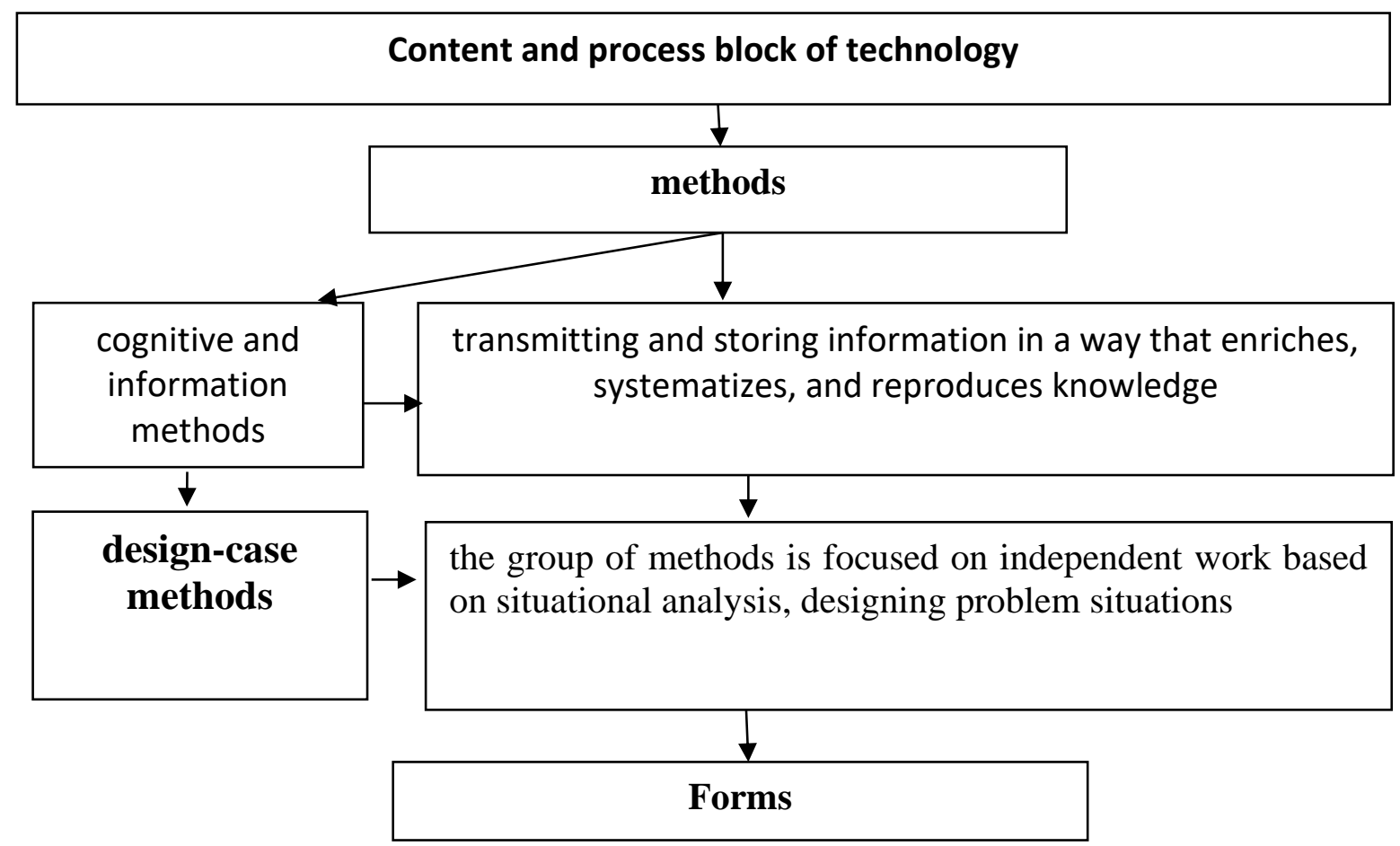

Lecture-discussion, lecture-panel, lecture using feedback technology, lectureconsultation, lecture-conference, interactive satellite lectures, slide lectures, computer video conferences, lectures with synchronous and asynchronous transmission of material, seminars, issue of almanacs, conferences

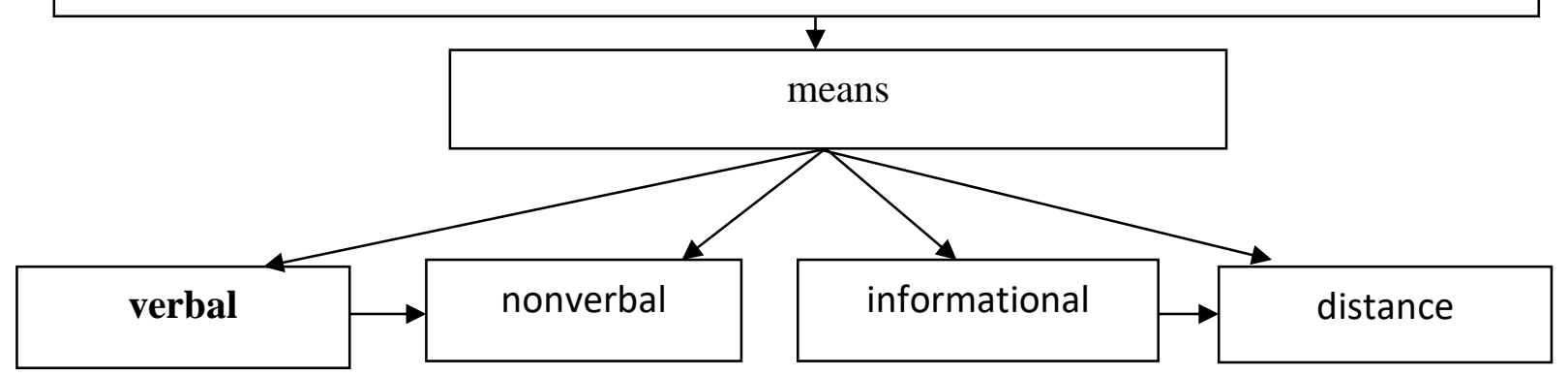


Figure 4. Method of designing technology for future teacher intellectual work culture formation.

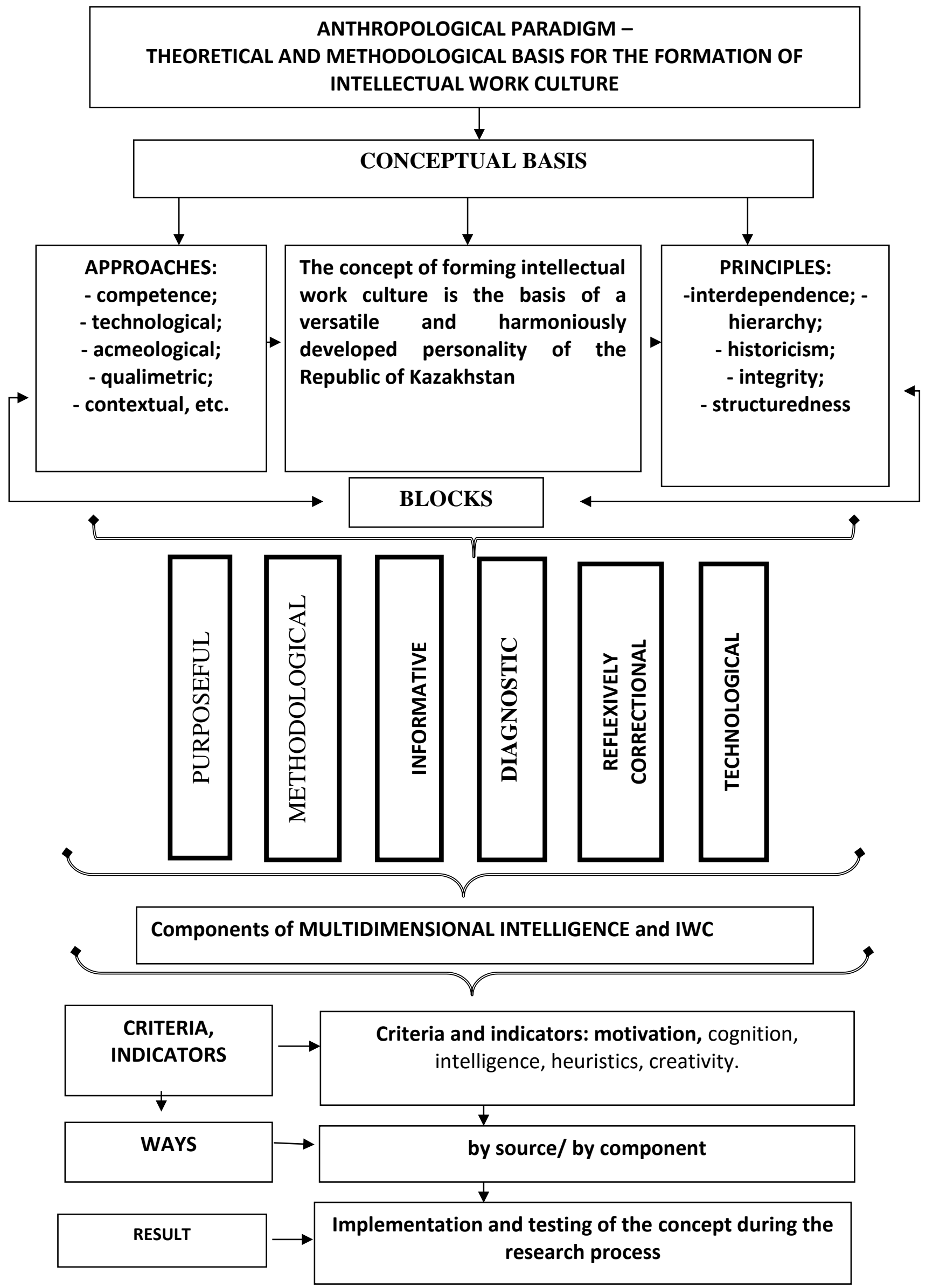




\section{Experimental stage}

During the experimental work, the level of intellectual work culture was diagnosed in the respondents of the experimental group consisting of 98 students. The control group involved 30 master students and 68 master students in experimental groups. The dynamics of changes in significant indicators of the levels of master students' intellectual work culture formation by components in the experimental group based on the results of the experiment is reflected in figures 5 and 6.

Figure 5. The dynamics of changes in significant indicators of the levels of master students' intellectual work culture formation by components in the experimental group based on the results of the experiment.

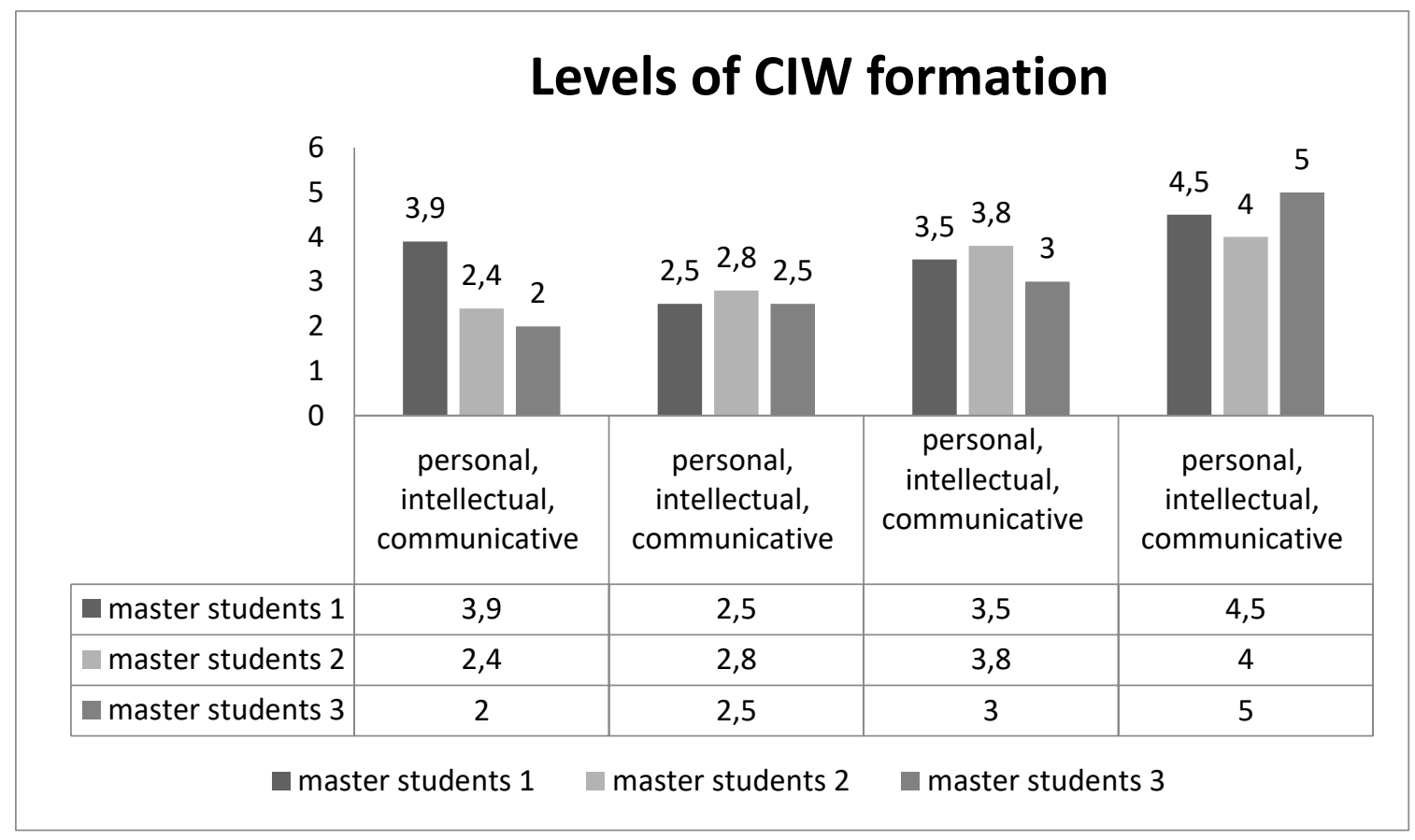

As a result of the study, $90 \%$ of respondents believe that knowledge of the culture of intellectual work is the main indicator of competence in the process of professional growth. These qualities are indicators of the effectiveness of educational and research activities.

The inclusion of master students in active activities during classes, seminars, conferences, contests "Portfolio of success", special seminars on the formation of intellectual work culture as a structural and process component of the anthropological paradigm in the learning process is aimed at activating the vital activity position of master students (Murzalinova, Ualieva, 2013), (Hivner, et al. 2019).

\section{Summary}

The study of literary sources allows us to state the absence of special studies devoted to the problem of developing a method designing technology for the intellectual work culture formation of a teacher and standardize the criteria, indicators and levels of achievement of students at the end of a certain stage of training. At the same time, to compare the learning results of a particular subject with a fixed compulsory minimum of mastering the content of education, with the requirements for the formation of competencies. 
Figure 6. The dynamics of changes in significant indicators of the levels of master students' intellectual work culture formation by components in the experimental group based on the results of the experiment.

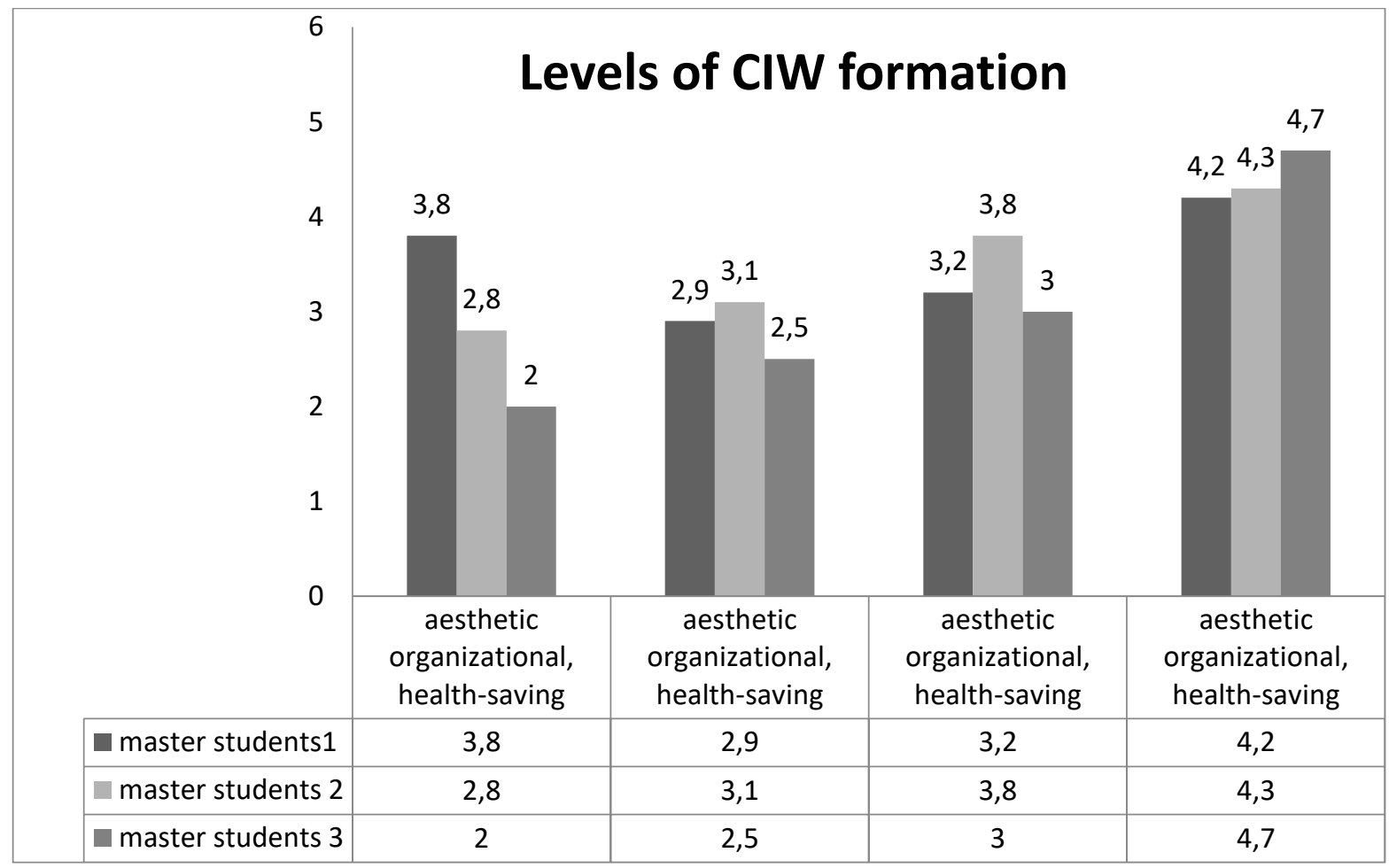

\section{CONCLUSION}

It is established that the identified psychological and pedagogical methods of designing the culture of intellectual work contribute to the transition of knowledge, skills and abilities into universal practical competence, and psychological processes and properties, states and mental education are transformed into personal competence.

The technology of intellectual work culture formation as a universal, psychological and pedagogical integrative system, aimed at personal, intellectual, communicative, aesthetic growth during the life-activity cycle of the individual. Understanding of ways, approaches and conditions that are defined as components of the system affect the high level of the intellectual work culture formation.

Acknowledgments: The work is performed according to the Russian Government Program of Competitive Growth of Kazan Federal University and S. Toraighyrov Pavlodar State University.

\section{REFERENCES}

Adilova, V. K. (2017). Formirovanie kultury intellektualnogo truda buduschego spetsialsta: teoriya, tekhnologiya, praktika [Formation of intellectual work culture of the future specialist: theory, technology, practice] Monograph, Pavlodar, Kereku Publ., 2, pp. 89-94.

Amhag, L. Hellström, L. Stigmar, M. (2019). Teacher Educators' Use of Digital Tools and Needs for Digital Competence in Higher Education. Journal of Digital Learning in Teacher Education, 35(4), 203-220.

Araujo, A., \& Silva, I. P. (2020). Maker culture and educational robotics in physics teaching: developing an automated traffic light in high school. Journal of Research and Knowledge Spreading, 1(1), e11654.

Barinova, N. A., \& Karunas, E. V. (2015). Individual educational program design as a consequence of FSES realization. Kazan Pedagogical journal, 3, 70-75.

Hivner, E. A., Hoke, A. M., Francis, E. B., Lehman, E. B., Hwang, G. W., \& Kraschnewski, J. L. (2019). Training teachers to implement physical activity: Applying social cognitive theory. Health Education Journal, 78(4), 464-475. 
Kuzmina, N. (1995). Tvorcheskij potencial specialista. Akmeologicheskie problemy razvitija. Humanization of education-Russia, 1, 63-66.

Mezinov, V. N., \& Zakharova, M. A. (2019).Teacher training for the development of social intelligence in schoolchildren. Education and Self Development, 14(2), 105-115.

Murzalinova, A. Z., \& Ualieva, N.T. (2013). Lifelong education as a driving force for personal self-development / lifelong Learning: traditions, innovations, perspectives: Materials of the International Forum, Kokshetau: Subsidiary company JSC NCDS "Orleu" "IPC on the Akmolinskaya oblast", 5, 21-28.

Oliveira, A. M., Gerevini, A. M., \& Strohschoen, A. A. G. (2017). Diário de bordo: uma ferramenta metodológica para o desenvolvimento da alfabetização científica. Revista Tempos e Espaços em Educação, 10(22), 119-132.

Potashnik, M. M. (2006). Kachestvo obrazovaniya: problemy tekhnologii upravleniya. Moscow, Pedagogicheskoe obshestvo Rossii Publ.

Rodrigues, B. M., Santos, J. E. B., \& Vasconcelos, C. A. (2020). Conceptions of undergraduate students in Chemistry on the use of interactive interfaces in and for the activities developed in the distance course. Journal of Research and Knowledge Spreading, 1(1), e11649.

Santos, J. E. B. (2020). Cartographic narratives: the teaching of mathematics and ICT. Journal of Research and Knowledge Spreading, 1(1), e11645.

Slobodchikov, V. I., \& Issaev, E. I. (1995). Osnovy psikhologicheskoi antropologii. Psikhologiya cheloveka: Vvedenie v psikhologiyu subyektivnosti. Textbook for HEls, Moscow, Shkola-Press Publ., 84-90.

State program for the development of education and science of the Republic of Kazakhstan for 2016-2019 and the project until 2025, 1, 2-6.

Yarullin, I. F., Nasibullov, R. R., \& Khuziakhmetov, A. N. (2018). The Problem of Prospective Teachers' Active Citizenship Development. Modern journal of language teaching methods, 8(10), 334-340.

Received: 03 January 2021 | Accepted: 2 February 2021 | Published: 16 February 2021

This is an Open Access article distributed under the terms of the Creative Commons Attribution License, which permits unrestricted use, distribution, and reproduction in any medium, provided the original work is properly cited. 